\title{
LIV. Description of the menagerie at Schœnbrunn in Austria
}

\section{Marcel de Serres}

To cite this article: M. Marcel de Serres (1816) LIV. Description of the menagerie at Schœnbrunn in Austria, Philosophical Magazine Series 1, 47:216, 249-257, DOI: 10.1080/14786441608628457

To link to this article: http://dx.doi.org/10.1080/14786441608628457

册 Published online: 27 Jul 2009.

Submit your article to this journal

Џ Article views: 3

Q View related articles $\square$

Citing articles: 1 View citing articles 5 


\section{Description of the Menagerie at Schonbrunn in Austria. 249}

As Sir $H$. Davy had recommended that the wire cylinder should be oiled when not in use, to preserve from oxidation, it was of importance to ascertain whether, should the flame of the fire-damp from its intensity set fire to the oil on the internal surface, it might not, by possibility, communicate with that on the exterior. For this purpose I obscured with naphtha on both sides a central portion of wire-gauze containing 3,600 meshes to the square inch, and having ignited this on one side, 1 found it did not communicate with that of the other, nor to slcohol, ether, or sulphuret of carbon applied by means of a camel hair pencil. I find I can even burn alcohol on each side, separated only by the fine open curtain of wire-ganze, without the flames "mingling into one," and this is beautifully illustrated from different colours being imparted to flaming alcohol by nitrates, copper, and strontites. My experiments with inflammable gases led to similar results.

I could not, by means of the blowpipe, force flame through this plexus, even when red hot, to fire ether applied by a pencil to the opposite side. I need not insist on the varied experiments I instituted. The application of wire-gauze to cut off the cornmunication of flame is as extensive as the necessities and conveniences of life. Enveloped in a mantle of wire-gauze lined with woollen, we may run the gauntlet of flame, and defy its power.

Imprisoned in the cylinder of wire-gauze the captive firedamp possesses no cause for alarm, exhibiting to the astonished eye an impressive and beautiful phænomenon.

I am respectfully, sir,

Very obecilently yours,

Whitehaven, April 2, 1810.

J. Murrat.

LIV. Description of the Menagerie at Schonbrunn in Austria. By $M$. Marcel de Serres*.

$\mathrm{T}$ HE menagerie of Schonbrunn is the most extensive in Eurepe. All the animals which it contains are separated from each other, and have a commodions asylum against the severity of the weather, and abundance of space for exercise. It is in the valleys of the fine park of Schoenbrunn that the dens or cages are to be seen for the various animals. The extremity of these rows of cages is merely closed with an iron gate, and the public have therefore a full view of all the animals in the menagerie. All of them have every thing they want beside them. Thus they have

* Annales des Arts et Mlunqfactures, tume Iv. p. 248 . 
water in which to bathe, a thick shade to screen them from the sun, as well as an open field in which they may enjoy its ravs.

Several very rare animals have lived in the menagerie of Schœnbrum: but we shall only instance at present the will ox of Transylvania, known to naturalists by the name of aurochs (Bos wrus), a species remarkable for the crest or mane it presents on its back. The aurochs is now an almost extinct breed, and it is only in Lithuania that it is to be met with: it should seem as if this species had been very a! Jundant in the forests of that part of Europe, as well as in those of Hungary. Thus, as we have had occasion to observe in the living state the animal designated by Aristotle as the bonasos, and which the moderns had particularly distinguished by the name of aurochs and bos un us; we thought that the description of an animal so rare might be interesting to naturalists. We have therefore been induced to publish the following observations, which we had collected respecting an animal that naturalists have so seldom seen. This description might also have a high degree of interest, since the bones of the same individual which we have seen living, are deposited in the Natural History Museum at Paris.

The aurochs, or wild ox of the north of Europe, is a species known since the time of Aristotle, who alone of all the Greeks has left us a detailed description, in designating them under the name of frnasos. While thus designating the aurochs, the Pæonians called it monapos, and it seems that it was still known under the name of monops, of monetos, and of monapos. As, subsequently, various Latin authors have erroneously distinguished two kinds of wild oxen, some moderns, thinking they discovered the second species in the bison, have thought that the Greek expression bonasos was a translation of the CeltoScythian word won'nas, formed of the article as and the Sclavonic word wonny, which signifies perfume. Thus, as Aristotle observed that the bonasos was called by the Pæonians monapos; this latter word has been derived from monapux, signifying having a thick mane. It is evident that all these etymologies may be well founded, since the aurochs exhales a vesy perceptible smell of musk, and presents a thick mane; but they are far from proving the opinion which is sought to be drawn.

The description given by Aristotle of the aurochs is too detaileu to permit us to quote it entirely; but we shall give the principal heads of it: "The size of the aurochs is that of a bull, but shorter and thicker than the ox. Its skin is so large that it may serve as a bed for seven persons. Its mane is covered with softer and longer hairs than that of the horse. The breast of the bonasos is fawn-coloured, and its mane is of a reddish 
gray, and falls over the eyes and shoulders. The hair of the lower part or belly is darker, and like wool." Its feet are cloven, and the teeth as well as the interior parts are similar to those of the ox. The arrangement which Aristotle gives to the horns of the aurochs - of being folded and bent over each other in such a way that they cannot strike-is a peculiarity of the individual which Aristotle had before him; and which must have been correct; for he repeats the description twice. We know however that this character can scarcely be regarded as constant, since it varies in the same individual. Lastly, he assigns to each horn the size of a palm or upwards.

With the exception of the fable which Aristotle relates on the subject of the excrements of the aurochs, and which Pliny and Elian have carefully preserved, the description of this great naturalist is distinct and clear. Finally, he assigns Pronia as the country of the bonasos, and says that it iuhalits Mount Menapius, which separates Pæonia from Media. Pliny, in afterwards copying the description of Aristotle, docs not endeavour to ascertain what animal could be the bonasos of the Greek naturalist ; he merely contents himself with saying: "Tradunt in Pæonia feram, quæ bonasus vocatur, equinầ jubâ, cætera tauro similem, cornibus ita in se flexis ut non sint utilia pugnæ; quapropter fugâ sibi auxiliari reddentem in eâ fimum interdum et trium jugerum longitudine: cujus contactus sequentes ut ignis aliquis amburat." Hitherto Pliny only speaks of one species of wild ox, as well as Aristotle; but in other places he designates two, since he says: "Jubatos bisontes excellentique vi et velocitate uros quibus imperitum vulgus bubalorum nomen imponit." He also returns to those two species of oxen; and observes that the Greeks had not experienced the medical properties of the wild oxen or lisons, with which the forests of India are filled. Plin. Hist. Nat. c. 28.

Solinus in copying the Latin naturalist also distinguishes two kinds of wild oxen; and he asserts that in the forests of Hyrcania the bisons are very common as well as the urus, and that these are the oxen distinguished by the vulgar under the name of bubalus. Oppian speaks of the bonasos in a manner as inexact as Pausanias, who, in describing the bulls exhibited in the spectacles at Rome, does not give the name of bonasos, but rather bison, making it come from Pæonia, the country of the former, as Aristotle had observed.

Cæsar, always accurate in his details, has decribed the bonasus of Aristotle by the name of urus. But he has described only one species of wild bull which he had observed in the forests of Hyrcania. This animal, he says, is very large, having the co. 
lour, stature, and carriage of a bull : their strength and agility are also, as he says, extreme *

Virgil in his Georgics, like Julius Cæesar in his Commentaries, makes mention of only one species of wild ox, which he also calls urus.

In the second book of his Georgics we find the following passage :

"Texenda sepes etiam, et pecus omne tenendum est,

Pracipue dum frons tentra imprudensque laborum;

Cui, super indignas hyemes, solemque potentem,

Sylvestres uri assidue, capreaque sequaces

Illudunt."

Geor. lib. ii. v. 371.

In his third book he returns to the subject;

"Tempore non alio dicunt regionibus illis

Quasitas ad sacra boves Junonis, et uris

Imparibus ductos alta ad donaria currus."

Geor. lib. iii. ver. 531.

Seneca and Martial distinginished, like Pliny, two species of wild oxen :

"Tibi dant vari氵e pectora tigres,

Tibi villosi terga bisontes,

Latisque feri cornibus uri."

SENEC. Hyppol.

"Illi cessit atrox bubalus atque bison:",

Martial.

As Pliny had already designated the Zonasos of Aristotle by the name of bubalus, it is evident that Martial had Pliny in his eye.

Thtts the ancients, with the exception of Cæsar and Aristotle, distinguished two kinds of wild oxen, which the moderns have endeavoured to trace : but the inquiry has led most of our moden naturalists to think that the oxen with humps on the shoulders were of the same race with the aurochs, and that all oxen with or without humps came from the wild ox of Lithuania. Gessner was the first modern naturalist who distinguished the bison of the ancients from the urus; and his opinion in addition to Buffon's has rendered the difficulties on the subject more intricate. It is important, in short, to know if the lisons of the ancients were the same species with the bonasos of Aristotle, and if the oxen of the new continent, called improperly lisons, belong also to the same race. Lastly, if the domestic oxen came

* Lib. vi. 26. The edition of Julius Cæsar, by Clarke, printed at London in 1712, gives a very large figure to the aurnchs, but it is very in: accurate. The neck and forc legs are by far too short, and the antcrion part is by far too broad. 
from the wild oxen of Pæonia and Lithuania, or rather from another primitive stock. 'The most illustrious naturalist of our days (Buffon) endeavours to throw light on these delicate questions, without doing so, however, in the most satisfactory manner. Messrs. Cuvier, Lacépède, and Geoffroy have together nearly set the matter at rest. It results from their observations:

1. That it appears very clear that the bonasos of Aristotle is the same animal with the urus of Julius Casar, and that the bison of the Romans is this very bonasos, to which the appellation of bulialus has also been given.

2 . That the ox with the hunch of the new continent, named improperly lison, is a species of ox which has nothing in common with the bonasos of Aristotle, who does not seem to have known the ox with the hunch. Besides, if Aristotle had known an ox with a hunch, he would not have asscrted in the same place where he spacals of the lonasos, that the camel was the orly quadruped which had a hunch on the back.

3 . That we ought to acknowledge the zebra as the source of our race of domestic oxen, rather than the aurochs, which differs from the former by characters which it is not usual for nature to vary.

4. That the name of urus, applied by Julius Cæesar to the animal just described, might be a name originally German, as Aldrovandus and Gessner have already imagined; and this opinion appears to us much more probable than that of Macrobius, who regarded the name of urus as a French word. In fact, the Germans still designate the urus by the name of auer-ochs, waldochs, and $u r$-ochs, which signifies properly wild ox, or ox of the forests. Those who are familiar with the German language know how easy it is to imagine that the varieties in pronunciation adopted in Germany might have changed the word urus into aurochs: the fact is, the former is merely a softer pronunciation of the word. Servius explains the word urus in a manner much more learned; and he derives it from the Greek word ogos, which signifies mountain.

\section{Descripition of the Aurochs or Bos Urus.}

The size of the aurochs does not much surpass that of our largest-sized domestic oxen: hut its form is much thicker and squatter. This thickness is the more remarkable when we compare it with the anterior part of the body of the urus, which is much broader. This greater breadth is particnlarly remarkable in the legs. But their larger size seems to depend merely on the muscles; for in the skeletons of the various species we do not remark any very marked differences. 
The shape or contours are rugged, and not soft or round like those of the domestic ox, and all its limbs strongly indicate in some measure its savage nature and great strength. The thick and woolly mane which covers all the anterior part of the body of the aurochs, and the thick beard which hangs below its chin, give it a wild air, which the intenseness of its stare and its sombre and grave countenance render still more striking.

The head of the aurochs is very broad, nay, even almost square. In its greatest breadth it measures eleven inches five lines, while its greatest length is 18 inches. If we compare the breadth of the head of our domestic oxen with that of the aurochs, we find that they are nearly as 3 to 4 . The forehead of the aurochs is also broader than it is high, and it is full and swoln, but less so than that of the buffalo.

This last character is even particular enough to enable us easily to distinguish this species from that of our domestic oxen, which have their forehead flat and a little concave. This disposition of the forehead with that of the horns separates those two species: thus the horns of the aurochs are not placed on the same level with the upper line of the forehead, but rather below, so that they form with the line of the forehead an acute angle. The horns of the common ox are on the contrary more elevated than the line of the forehead, so that they form with: it an almost obtuse angle. As to the plan of the occiput, it is quadrangular in the domestic ox, while it is semicircular in the aurochs.

The salient angle of the interorbitary arcade forms in the aurochs a marked prominence of two inches, which is very considerable. The anterior of the head of the urus, the part where the nostrils are placed, is singularly flat and square in this species. This flatness is not found in any other species, and seems to be a character peculiarly inherent to the latter. The nostrils of the aurochs have this particularity, that they form almost a perfect circle; whereas those of the buffalo and domestic ox are decidedly oval. As to the black skin of the nustrils, it is thick and solid, and forms a thick flap.

The head of the aurochs is very hairy, and it is particularly under the chin that it presents a thick and occasionally a long beard. The ears of this species of ox are short, hairy, and placed behind above the horns. As to the horns, as their direction is subject to vary, and as the same individual presents them sometimes in opposite directions, we shall not stop to describe them. We shall content ourselves with observing here that this direction is never from front to back, as in the buffalo for instance; besides, in this species they are thick and broad, 
but short: this is not the case always in the races of our domestic oxen ; for instance, in the varieties of the oxen of Hungary, and even of Romania, which have very long horns.

The urus has a broad but short neck, and we do not see that the skin ever forms numerous and pendent folds, as observed in the domestic ox, and in the greater number of the species of this genus. It is generally very hairy and covered with a thick mane, which always becomes thicker towards the lower part. It is this mane which has made this species be confounded by several naturalists with the bison of the new continent, which seems to have a mane still more abundant.

The form of the body of the aurochs is generally thicker than that of the domestic oxen, and its body is also much more hairy, particularly in the fore parts and on the back. The hairs are generally very long and very thick. Finally, the aurochs has fourteen pair of ribs, while we observe but thirteen in all the other species of oxen.

The legs of the urus are short and thick, particularly the fore legs : they are also covered with long and numerous hairs; the feet are cloven and hairy, the hoofs are short, but strong and thick : as to the fetlocks, they are long and placed above the hoofs. From the direction of these fetlocks they almost touch the ground : those of the fore feet are shorter and more square than those of the hind feet, which are longer, but also not so broad.

The tail of the aurochs scarcely reaches half down the thigh; but the hair which covers it touches the ground: it is tufted, and the hair is long and thick.

The breast of the aurochs which we saw, was of a reddish brown, or of a dull fawn colour, and almost of one tint: the hair of the body, as well as the mane which covered the whole of the neck and part of the shoulders, had not that grayish tinge which Aristotle makes one of the cliaracters of the bonasos. The hair of the urus is not short and frizzled, but, on the contrary, long and straight, and in the individual just mentioned it is of a generally uniform colour.

The auroshs presents, therefore, as its chief characters : a face very flat, the forehead slightly swoln, the horns placed below the line of the occiput, and the interorbitary arcade very salient : Lastly, a thick mane and fourteen pair of ribs. The characters presented by the occiput, of being arranged in a semicircle, and of forming an obtuse angle with the forehead, are also equally important, and may very clearly serve for the distinction of this species.

The dimensions of the aurochs are as follow:

Length following the curvature of the back, nine feet three inches. 
Length from the orbit to the anus, seven feet seven inches. Height taken at the highest point of the back, five feet nine inches.

Length of the head, one foot ten inches.

Breadth, one foot four inches.

Length from the extrenity of the nostrils to the extremity of the eye, one foot.

From the extremity of the eye to the root of the horns, five inches.

Breadth of the horns taken at their hase, four inches.

Length of the neck to the shoulder-blade taken obliquely, one foot five inches.

Height from the hoof of the fore foot with the different curvatures to the nost elevated part of the back, five feet nine inches.

Space between the train behind and the train before, two fect eight inches.

Height from the fore foot to the chest, two feet five inches.

Height from the fore feet to the line of the body, two feet two inches.

Height from the hind feet measured to the line of the body, two feet seven inches.

Length of the neck, one foct eight inches.

Length of the tail, four feet.

We may refer to the aurcehs the descriptions and figures under mentioned.

1. The species which Aristotie has described by the name of bonosos.

2. The species of oxen deseribed by the Greeks by the names of monapos, monepos, and monops.

3. The oxen described by Pliny, under the names of Gonasus, bubalus, and bison, as well as all those which the ancient Latin authors called by these names. We must not confound with the aurochs the species which some moderns have described isy the name of bubalus, which is nothing but the buffalo.

4. The urus of Julus Cesar and Virgil.

5. The figures of Aldrovandus are so inaccurate that we cain scarcely refer to the aurochs that which he gives of the urus. As to Johnston, as he has adopted the opinion of certain Latiit authors in distinguishing the two species-of wild oxen, he has also given drawings of them. In plate xix. he has given the lonasos; and in plate $\mathrm{xx}$. the urus. If these two fignres wera accurate, they would certainly indicate two very different animals; but when we consider the little credit which Johnston deserves, we camot refer to them with propriet: 
6. The ox figured in the Commentaries of Sigismond D'Herberstein.

7. The ox represented by Arthony Wied in the Map of Muscovy.

S. The ox represented in the large edition of Julius Cæsar published at London by Clarke. In this figure the feet are represented by far too small to support the mass of the body.

9. The zimbre or wild ox of Moldavia, or the zulier, zubr, tur or turon of Poland, is certainly the aurochs.

10. The white bison of Forster and Penuant is only a variety of the aurochs.

11. The figure of the female urus, given by Gilibert in his History of Quadrupeds.

12. The figure of the aurochs of Bertuch, plate xiv. fig: 1, which is to be found in the Tafeln des Allgemeinen Naturgeschichte. The figures given by Bertuch are so small, and in general so bad, that we can place hut little confidence in them.

13. The descriptions which Pallas has given of the urus are exact, and he also cites another description of the anatomist Wilde, which has the same advantage.

The aurochs which we saw was a male, which had lived thirty years in the menagerie. It came from Transylvania. In a fire which broke out in the place where it was kept, it owed its preservation to its great strength ; for it broke the chains by which it was fastened, dug up the door of its den, and overthrowing every obstacle escaped from the flames. This great strength of the aurochs would make it very valuable if it could be trained for domestic purposes; but all the attempts made to tame this one at Schœenbrunn were fruitless. When I saw it, it was not quite so ferocious, for age had diminished its strength. The branches of trees which had been given it for fond, and of which it was very fond, had so worn down its teeth that it could no longer digest but with pain, not being able to masticate. It died soon afterwards of consumption.

The aurochs is a species almost lost in the present day: some few individuals only are found thinly scattered in the forests of Lithuania and Transylvania. We are assured that there are some in the Krapac Mountains also. It appears that it was formerly very common in some temperate regions of Europe. The descriptions of ancient Latin authors give us every reason to believe so.

The individual which we saw at Schocnbrunn emitted a hoarse but very strong sound, and which had something in it sad and mournful: it roared, but never bellowed like an ox. When it was frightened or crossed in any way, it roared so loud that its keepers were frequently terrified for the consequences.

Vol. 47. No.216. April 1816.

$\mathrm{R}$

LV. On 